\title{
TOWARD ECONOMIC REWARD: CORPORATE SOCIAL RESPONSIBILITY COMMUNICATION OF SMES
}

\begin{abstract}
In business world of today, small and medium-sized enterprises (SMEs) play the part of an increasingly important role in the world economy. Currently, SMEs are thought to be the backbone of economic growth in many countries, contributing to the creation of job opportunities and acting as suppliers of goods and services for large organizations. Internationally, various studies are related to the importance of SMEs for a country's development and economic stability. SMEs also play an important role in European economies and their form according to some authors is a pillar of business structure. Academics emphasise in many ways Corporate Social Responsibility (CSR) as a mantra for our time, a time which they characterised as "the era of compassionate capitalism" or "the age of sustainability". CSR communication is an important element of the strategic approach to communication, which rests on the idea that enterprises can create a strong identity by implementing a systematic and proactive strategic communication practice within their organisations, establishing the way for "the building and maintaining of favourable reputations and relationships with key stakeholders".

Key words: Corporate Social Responsibility (CSR), CSR Communication, Small to Medium Sized Enterprises (SMEs)
\end{abstract}

\section{Introduction}

In today's business world, new enterprises are perceived as an important source of job creation, innovation and development. ${ }^{1}$ Longo, Mura and Bonoli feel that in the entrepreneurial world the choice of aims to be pursued is a mat-

Mr.sc. Ana Mulović, University North, Koprivnica, Croatia, e-mail: ana.mulovic@unin.hr

** Assistant Professor Anica Hunjet, PhD, University North, Koprivnica, Croatia, e-mail: anica.hunjet@unin.hr

*** Associate Professor Goran Kozina , PhD, University North, Koprivnica, Croatia, e-mail: goran.kozina@unin.hr

1 Pistol, L., Tonis, L. (2014): “ odels of marketing simulations for SMES in Romania: Strategic gaim for marketing mix simulation", Contemporary Readings in Law and Social Justice, 1,2014, 500 . 
ter that is frequently trivialized and does not receive the attention it deserves. The objectives of a enterprises, observed by them, are taken for granted and are identified, from case to case, with the profit or the production of wealth or the creation of value for the shareholders; and it is presumed the matter ends there. ${ }^{2}$ Due to global competition, technological progress and the new needs of consumers, competitive paradigms are in constant change and those changes are leading enterprises to compete simultaneously in different dimensions such as design and product development, production, distribution, communication and marketing. ${ }^{3}$ Currently, small and medium-sized enterprises (SMEs) face increasingly more complex and dynamic contexts where obtaining and maintaining competitive advantage is certainly rather complicated and one of the main objectives is full consumer satisfaction, not only with the use of the product but also regarding the externalities generated by companies. ${ }^{4}$ Therefore, concepts like Corporate Social Responsibility (CSR) arise as strategic concepts because they allow firms to position their objectives and activities in line with society.

\section{The role of small and medium sized enterprises}

Nowadays, the new enterprises are recognized as the main source of job creation, innovation and further development. ${ }^{5}$ Small and medium-sized enterprises (SMEs) play an increasingly important role in the world economy, and are considered the backbone of economic growth in many countries, contributing to the creation of job opportunities and acting as suppliers of goods and services for large organizations. ${ }^{6}$ On an international level, various studies are related to the importance of SMEs for a country's development and economic stability. ${ }^{7}$ SMEs have characteristics that distinguish them from large organizations and these differences are not limited to size, but also involve objectives, management style and marketing itself. ${ }^{8}$ For this reason, authors claim it has been demonstrated that traditional marketing theories are not

2 Longo, M., Mura, M., Bonoli A. (2005): “Corporate social responsibility and corporate performance: the case of Italian SMEs”, Corporate Governance, 4, 2005, 29.

3 Franco, M., Santos, M. de F., Ramalho, I., Nunes. C. (2014): “An exploratory study of entrepreneurial marketing in SMEs: The role of the founder-entrepreneur", Journal of Small Business and Enterprise Development, 2, 2014, 265.

4 Fraj-Andres, E., Lopez-Perez, M. E., Melero-Polo, I., Vazquez-Carrasco, R. (2012): "Company image and corporate social responsibility: reflecting with SMEs' managers", Marketing Intelligence \& Planning, 2, 2012, 266.

Pistol, L., Tonis, L., 500.

6 Franco, M., Santos, M. de F., Ramalho, I., Nunes. C., 267.

Ibidem

Ibidem 
able to give a satisfactory explanation of marketing in SMEs. Therefore, the role of marketing in SMEs has aroused the interest of many investigators. ${ }^{9}$ The complexity of the business environment in which SMEs conduct their business is growing very fast. ${ }^{10}$

Importance and advantages of SMEs described by Franco et al. are summarized as:

- their size often allows them to obtain competitive advantages,

- organizational structures in small firms are much less rigid, sophisticated and complex than in large firms,

- simple systems and procedures, which permit flexibility, immediate feedback, a short decision-making chain, and better understanding of and a faster response to customer needs. ${ }^{11}$

Significant questions are also asked and appeared in the work of Longo, Mura and Bonoli in the following form: "Which is the objective that administrators and managers should pursue? Should it be that of making the maximum profit or should the objective be a vaster one, in order to create value for all the stakeholders? In the latter case, what does this vaster objective consist of? Who are the stakeholders of the company and what are their expectations regarding value? Are the responsibilities of administrators and managers only those established by law or do these people have further responsibilities in addition to the legal ones, namely responsibilities of ethical and social nature which oblige them to serve their customers' needs in the best way possible, to respect and make the most of collaborators, to participate in environmental issues beyond the limits prescribed by law, and so forth?"12

\section{Morality of small and medium-sized enterprises and usage od corporate social responsibility concept}

A new sense of morality has appeared in many parts of Western society where "companies are expected to share responsibility with governments for tackling issues which, in the old world economy, they would have been ignored in their pursuit of profit". ${ }^{13}$ SMEs and large companies share the environment in which they operate. Environment is characterized with:

Ibid., 266.

10 García, M., Castillo Díaz, A. and Carrillo Durán, V. (2012): “Online corporate communication: SMEs and differences across sectors", Journal of Organizational Transformation \& Social Change, 3, 2012, 287.

11 Franco, M., Santos, M. de F., Ramalho, I., Nunes. C., 267.

12 Longo, M., Mura, M., Bonoli A., 30.

13 Schmeltz, L. (2012): “Consumer-oriented CSR communication: focusing on ability or morality”, Corporate Communications: An International Journal, 1, 2012, 29. 
- economies that are global in nature and rich in information

- a competitive market led by intangibility and expressive and symbolic consumption patterns

- rapid innovation diffusion and product and service obsolescence; and

- crowded with cacophonous and abundant offerings. ${ }^{14}$

According to Fassin et al., a fter decades of renewed academic research into the importance of the idea that business organisations have social responsibilities, the concept and the usage of Corporate Social Responsibility (CSR) remain complex, multifaceted and prone to national interpretations..$^{15}$ Longo, Mura and Bonoli agree that it is not simple to propose a univocal definition of CSR despite there being a vast amount of literature on the subject. ${ }^{16}$ Ayuso, Roca and Colome also pointed how a universally accepted definition of CSR does not exist but it become an increasing area of interest for both the business world and academic community. ${ }^{17}$

Schmeltz also argues CSR as in many ways a mantra for our time. A time which can be characterised as "the era of compassionate capitalism" or "the age of sustainability", and a time in which the traditional roles of companies, consumers, NGOs, state and society have changed dramatically. ${ }^{18}$ In their review of the literature authors divide the vast existing research on CSR into studies at three levels: institutional, organisational and individual. ${ }^{19}$ Ayuso, Roca and Colome state the CSR concept generally refers to "the responsibility of enterprises for their impacts on society" and focuses on the role of companies beyond their traditional scope of seeking profit, and evolved from emphasizing the social responsibility of business to incorporating also the concern for environmental protection..$^{20}$ From Longo, Mura and Bonoli literature review it is clear that the problems surrounding social responsibility are problems that concern the way a company is governed and run as well as the kind of relations it holds with its stakeholders. ${ }^{21}$ CSR concept also could be considered as an "umbrella" term, incorporating the tenets of; environmental sustainability, business ethics, gov-

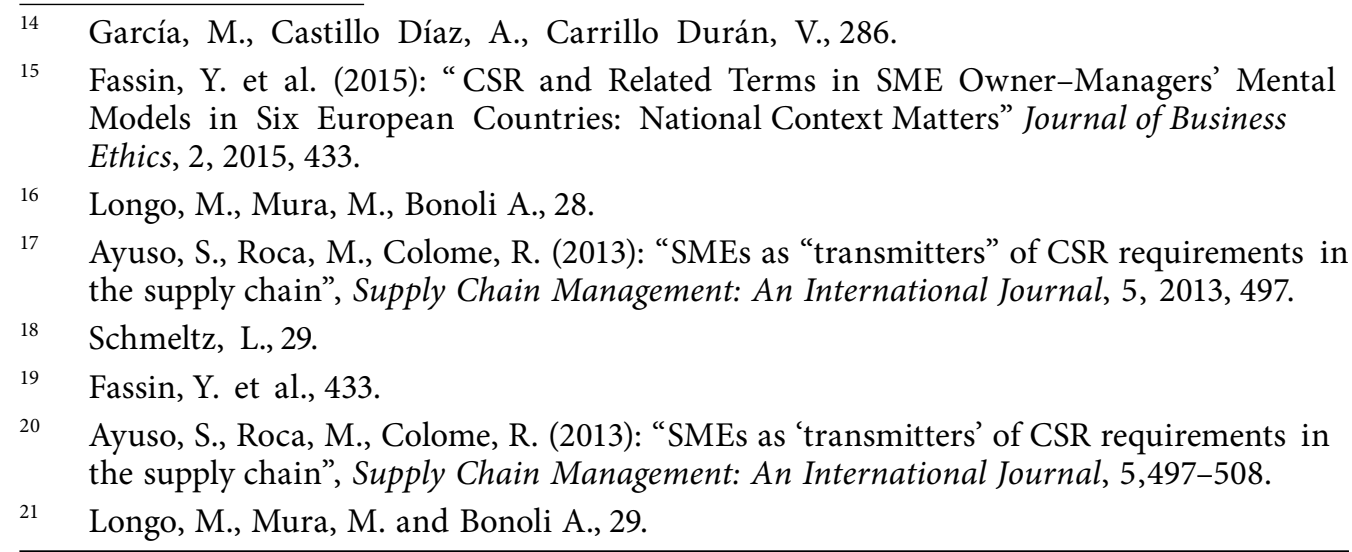


ernance, public relations, stakeholder analysis and relationship marketing. ${ }^{22}$ According to Nagypál, CSR concept and company level sustainability are popular issues among policy makers and company representatives. ${ }^{23}$

Longo, Mura and Bonoli provided significant contributions from previous researches and classify CSR into four classes: ${ }^{24}$

- Economic responsibility. The primary aim of any company is to make profit: without profit it is destined to close down. For this reason the company has, above everything else, an economic responsibility and only subsequent to this can any other kind of responsibility be taken into consideration. To honour this economic responsibility the company has the obligation to manufacture the goods and services society needs and sell them, thereby generating a profit.

- Legal responsibility. Companies operate within a society that has specific regulations, laws and standards of behaviour; society expects companies to respect these throughout their business activity.

- Ethical responsibility. The two classes of responsibility analysed above follow ethical codes of behaviour that society defines in the form of laws or by means of explicit expectations that companies cannot ignore and disappoint. By undertaking a moral responsibility companies voluntarily decide to satisfy certain expectations that, despite their not being explicit or backed up by regulations, are nevertheless expectations that society wants business to fulfil. Therefore, such expectations regarding the behaviour of companies transcend mere economic and legal considerations.

- Discretionary responsibility. Companies satisfy, once again voluntarily, expectations that have not yet become apparent in its interlocutors; it is the companies that anticipate needs and necessities and they satisfy them before they actually arise.

It is important to emphasise, while sustainability investigates the system of relationship of the "economy-society-nature triangle" starting from the macro level and from the aspect of global problems (effects), CSR does the same starting from the micro level, from one of the "causes" of the problems, the companies. ${ }^{25}$ However, Longo, Mura and Bonoli emphasised that the essential point of the CSR concept can be recognized in the voluntary undertaking of a commitment, towards third parties, by the management of a business

22 Barthorpe, S. (2010): "Implementing corporate social responsibility in the UK construction industry", Property Management, 1, 2010, 4.

23 Nagypál, N. C. (2014). "Corporate social responsibility of Hungarian SMEs with good environmental practices”, Journal for East European Management Studies, 3, 2014, p. 327

24 Longo, M., Mura, M. and Bonoli A., 30.

25 Nagypál, N. C., 328.

Vol. 12, No 3, 2015: 215-230 
and that undertaken commitment goes beyond the legal obligations that weigh heavily on the management of the company's activity. As two fundamental reasons for the difficulty, they encountered that: ${ }^{26}$

- it is not possible to fully define how far the responsibility extends, both on account of its complexity and of the manifold nuances it takes on with respect to the different stakeholders of the company; and

- there is only partial acceptance by experts of economic matters to unite in a single vision, with no priorities, the economic responsibility of the company towards third parties, in particular with respect to holders of capital at risk, with social responsibility.

Nagypál finds CSR concept as a self-defining one that involves several issue areas: ${ }^{27}$

- environmental protection,

- countering bribery,

- respecting employees' rights andphilanthropic activity as well.

When it comes to Nagypál, most of these areas are extremely relevant in the Central and Eastern Europe (CEE). However, in the latest communication by the European Commission, he found that the voluntary nature of CSR is not stressed any more, and that the definition only states that CSR is "the responsibility of enterprises for their impacts on society". He also highlights that European Commission communication emphasises "respect for applicable legislation, and for collective agreements between social partners, is a prerequisite for meeting that responsibility". According to Nagypál, there is still an open question whether, or to what extent CSR can contribute to sustainability goals. He also commented that there are some aspects of the CSR concept that make it more acceptable and feasible for companies than the "ambiguous" concept of sustainable development. ${ }^{28}$

According to Ellerup Nielsen and Thomsen, these days researchers agree that CSR is a contextual and dynamic concept, and that differences in CSR between different countries are due to a variety of "longstanding, historically entrenched institutions". ${ }^{29}$ The differences emerge "against a background of historical, political, scientific, cultural - and of course, business developments". ${ }^{30}$

\footnotetext{
26 Longo, M., Mura, M., Bonoli A., 30.

27 Nagypál, N. C., 328.

28 Ibidem

29 Ellerup Nielsen A., Thomsen, C. (2009): "CSR communication in small and mediumsized enterprises: A study of the attitudes and beliefs of middle managers", Corporate Communications: An International Journal, 2, 2009, 176.

$30 \quad$ Ellerup Nielsen A., Thomsen, C., 179.
} 
The new CSR strategy of the EU suggests that the scepticism about CSR, according to Nagypál, was partly established, as the communication published in 2011 highlights that CSR should be more definite and transparent, results should be more measurable and sector specific development is also desired. ${ }^{31}$ Nagypál also reveals that the special conditions of SMEs were also mentioned in this document, "...In implementing this agenda, the Commission will at all times take account the particular characteristics of SMEs, especially their limited resources, and avoid creating unnecessary administrative burden ${ }^{\text {“ }}{ }^{32}$ Nagypál observed that CSR is mostly interpreted as the contribution of large enterprises, corporations to sustainability, although the behaviour of SMEs due to their important role in economic production and employment as well as their consumption of natural resources and the total emission they are responsible for is essential to emphasize. ${ }^{33}$ However, business development in general also calls for an understanding and acknowledgement of the relevance of implementing CSR to achieve legitimacy among central stakeholders, and to increase business and market performance. ${ }^{34}$

\section{SMEs Europe overwiev on CSR contribution}

SMEs play an important role in the economy in Europe. ${ }^{35} \mathrm{~A}$ common characteristic of European economies is the fact that SMEs form is a pillar of their business structure. ${ }^{36}$ Nagypál made the point that former European Commissioner for Enterprise and Industry, Günter Verheugen stated: "SMEs are the engine of the European economy. They are an essential source of jobs, create entrepreneurial spirit and innovation in the EU and are thus crucial for fostering competitiveness and employment" ${ }^{37}$ On the other hand, governments and other public authorities in Europe are putting increasing pressure on SMEs in order to make them realise that respect for ethical codes of conduct and CSR is not only a concern of multinational corporations. ${ }^{38}$ Also, Longo, Mura and Bonoli agreed that the SMEs are particularly sensitive to the problems surrounding social responsibility: the small entrepreneur "experiences" in person, together with his family and his employees, the territory in which he operates, and shares with them both results and worries. The relationship

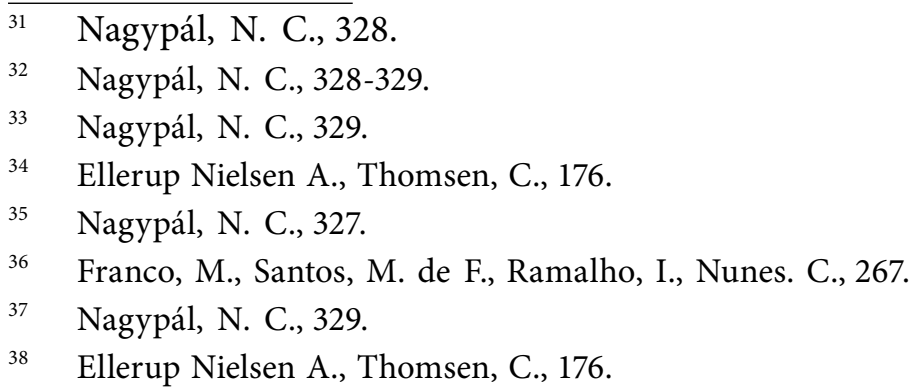


with the local authorities described as far closer and more direct than that of a large business. ${ }^{39}$ "Entrepreneurial spirit", according to Nagypál, should in an ideal case include a responsible attitude, that is, responsibility for internal and external stakeholders of the company. After reviewing latest sources Nagypál concluded how "the academic literature reveals the need to undertake more in-depth field studies in order to discover the organisational culture, the difficulties and the perceptions surrounding CSR in SMEs". ${ }^{40}$

Nagypál also provides a review of the CSR concept which was emerging in Europe as early as in the 1990s, getting popular in CEE region with some significant delay, from the mid 2000s. According to Nagypál, entering the European Union also contributed to the spread of CSR in new Member States, by making EU documents relevant and fostering the concept among decisionmakers. According to green paper of the European Union CSR is "a concept whereby companies integrate social and environmental concerns in their business operations and in their interaction with their stakeholders on a voluntary basis". ${ }^{41}$ On a further note, Nagypál recognized important role in CSR of SMEs in direction of closer relationship with local communities versus large enterprises. Author argues that it is a problem that CSR tools are usually developed and available for large companies with special management practices and even SMEs committed to responsible behaviour lack appropriate CSR tools and they are often far from realising the advantages of their positive attitude. ${ }^{42}$

Barthorpe emphasises how the UK government launched the "International strategic framework into corporate social responsibility" in March 2005 and the framework sets out the overall objectives, priorities, and the main lines of the UK government's approach to CSR. ${ }^{43}$

The survey among Italian SMEs that have been analysed showed that the majority of Italian SMEs companies have perceived the social responsibility concept as welcome one; it not only because they have moral or ethical reasons for doing so (51 percent of the companies examined), but also because they think that it contributes to the growth of the company's own value, by means of an improvement in company image, ensures the fidelity of customers and an improvement in relationships with employees and the local community. ${ }^{44}$

The survey among Hungarian SMEs, for example, showed that CSR of SMEs can be developed not only by direct financial support but also by improving awareness of their customers and motivating large companies to

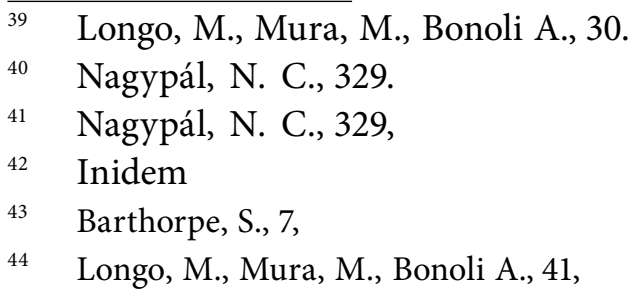


support their suppliers' action. ${ }^{45}$ The results of survey among Hungarian SMEs point out that even SMEs with good CSR practices know and apply relatively few CSR tools. According to Nagypál, one of the most important reasons for this is that these tools are usually developed for large companies. Results shows that some tools developed especially for this segment are completely unknown among respondents. ${ }^{46}$ Good examples present that still better cooperation along the supply chain and the development and application of more CSR tools and measures could improve awareness and performance of CEE SMEs, contributing to their competitiveness on European and world-wide markets and their sustainable development in the long run. ${ }^{47}$

Worth to mention are the findings among SMEs in Norway, that is closely associated with the European Union through its membership in the European Economic Area. These findings show that it is crucial to view the embedding process of CSR as part of a strategic implementation process, which is capable of interlinking and interlocking business goals with human, social and environmental objectives in order to foster a financially and socially responsible business. ${ }^{48}$

\section{Relevance of CSR communication}

Schmeltz observed that is no longer a sharp distinction between doing good, and doing business and pointed that often these two are compatible. ${ }^{49}$ According to Schmeltz, the value of working with CSR in a corporate context is, however, limited if the engagement is not communicated to relevant stakeholder groups. However, Schmeltz also made the point "Corporate Social Responsibility is an extremely difficult message to convey" ${ }^{50}$ According to Ellerup Nielsen and Thomsen, concepts such as stakeholder management, reputation management and supply chain management are now relatively widespread, so SMEs need to ask themselves whether they should increase their activity level and their communication or documentation of CSR. ${ }^{51}$ Further, Ellerup Nielsen and Thomsen described surveys and research in the field demonstrate that many SMEs tend to handle CSR activities unsystematically and on a personal

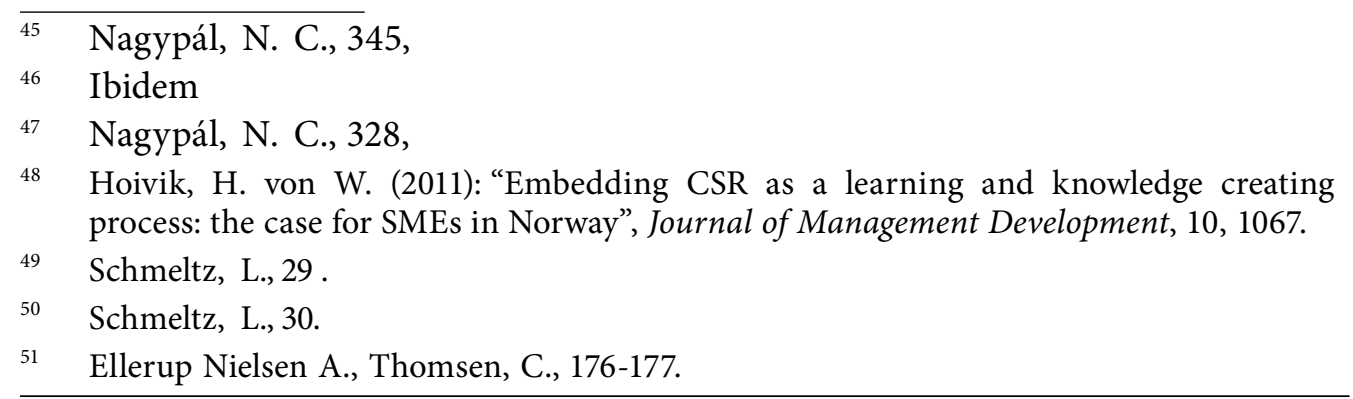


ad hoc basis. ${ }^{52}$ Authors indicate that in one hand, SMEs should learn from larger organisations when it comes to managing CSR and informing both internal and external stakeholders of their best practices and on the other hand researchers tend to agree that CSR communication is a delicate issue, the problem being that although corporations are encouraged to engage in CSR to build strong reputations, stakeholders are often reluctant to receive too much information about their CSR engagements. Despite the lack of research on small businesses and their communication activities, the SMEs are limited by their own conceptions. ${ }^{53}$ Paradoxically, communicating about CSR, a concept which is traditionally seen as a voluntary corporate initiative, is no longer optional but actually mandatory in some countries. ${ }^{54}$

Ellerup Nielsen and Thomsen argues CSR communication as an important element of the strategic approach to communication, which lies on the idea that companies can create a strong identity by implementing a systematic and proactive strategic communication practice within their organisations, paving the way for "the building and maintaining of favourable reputations and relationships with key stakeholders" ${ }^{55}$ Recently, reveals Ellerup Nielsen and Thomsen, the association of CSR with strategy is expressed in headings such as: CSR as organisation development, CSR as stakeholder management, CSR as reputation management, etc. Other attempts have been made to elaborate classifications based on matters related to CSR. ${ }^{56}$

Sones and Grantham describe CSR communication as a process inherently focused on the good deeds performed by the company in relationship with various stakeholders. Authors emphasize CSR goals and achievements as inspired by company top decision makers. Authors made a point that a decision-maker commitments are controlled partly by the formulation of the problem and partly by the norms, habits, and personal characteristics of the decision-maker. ${ }^{57}$

Ellerup Nielsen and Thomsen observed two models that may help to explain how companies can best make decisions about channel and issue and communicate about their CSR initiatives. First one is an "inside-out approach" that suggest how managers can manage their CSR activities to achieve a favourable CSR reputation. Second one develops a CSR communication model with two CSR communication processes targeting different stakeholder groups:

\footnotetext{
$52 \quad$ Ibid., 177.

53 García, M., Castillo Díaz, A., Carrillo Durán, V., 287.

54 Schmeltz, L., 30.

55 Ellerup Nielsen A., Thomsen, C., 178.

56 Ellerup Nielsen A., Thomsen, C., 179.

57 Sones, M. and Grantham, S. (2009): “Communicating CSR via pharmaceutical company web sites: Evaluating message frameworks for external and internal stakeholders", Corporate Communications: An International Journal, 2, 144.
} 
"the expert CSR communication process" and "the endorsed CSR communication process", the former being direct and the latter being indirect, legitimised or endorsed by a third party. ${ }^{58}$ While direct communication typically passes through formal channels and genres such as social or sustainability reports, web sites or brochures, etc., indirect communication typically finds its way to target groups through gatekeepers such as journalists of the local press, mouth-to-mouth communication from employees to local community actors or consumers, etc. ${ }^{59}$

According to Schmeltz, companies tend to shy away from the communication aspect of CSR, either because they are not comfortable communicating their own view on corporate responsibilities, or because they are oblivious of the critical importance of such communication activities. Equally author argues that in the academic world, many theorists and researchers have contributed to the field of CSR, but without paying much attention to the rhetorical and discursive challenges of CSR. ${ }^{60}$

\section{Conclusion}

Based upon survey, SMEs primarily associate the idea of reputation being a good workplace, which is considered a strong point in itself. Furthermore, in order to benefit more from being a good workplace, SMEs need to strengthen both their direct and their indirect communication, for example by drawing on the national and the local press. Results of Ellerup Nielsen and Thomsen survey in a strategic communication perspective, shown that SMEs need to reflect on how to strengthen and develop their identity and their image or reputation as good corporate citizens. ${ }^{61}$ Authors describe, for instance, by incorporating relevant press networks SMEs will be able to benefit more from the PR potential inherent in their regular exposure in newspapers and journals (business portraits, debate columns, chronicles, letters from readers, etc). They emphasise that only in this way can they improve their indirect communication to the public and to the community and attract attention to the many good things they do. Other (perhaps less expensive) initiatives could involve identifying the potential for exposure in business networks, cross-sector partnerships, awards, etcetera. Various forms of cooperation with students and other forums also constitute a platform for exploiting their communication potential more explicitly. Mentioned survey described that many business-to-business SMEs are known only to their own employees, customers and suppliers. By using the intranet

\footnotetext{
$58 \quad$ Ellerup Nielsen A., Thomsen, C., 179.

59 Ellerup Nielsen A., Thomsen, C., 180.

60 Schmeltz, L., 30 .

${ }^{61}$ Ellerup Nielsen A., Thomsen, C., 186.
} 
together with external web pages, and by focusing on the possibilities offered by interactive technology such as debate forums and weblogs, SMEs can strengthen their formal communication in a manner which will not necessarily be perceived as self-promotional by critical stakeholders. ${ }^{62}$

Good practices can been seen on Hungarian market which include the specialisation of some non-governmental organizations on development and introduction of "SME oriented and tailored" tools, such as "eco mapping" or "Eco Management and Audit Scheme easy". ${ }^{63}$ Another recent remarkable initiative from the same market was that a large Hungarian bank assisted 50 SMEs in becoming acquainted with ISO 26000 - a standard about CSR, developed by ISO in a long-term process, involving stakeholder dialogue - in $2011 .{ }^{64}$ The European CSR award is also available for Hungarian companies as well, there are two categories in which one can apply: large companies and the SMEs. It is also a great opportunity for SMEs to improve and communicate their commitment and action. All of the above is example of good practice also applicable to other markets and further encourage SMEs on their CSR communication.

In addition, authors emphasise that the very organisation of CSR can in itself strengthen the CSR profile of SMEs. ${ }^{65}$ One possibility for them is to consider marketing and perhaps also PR as a function that is closely related to the general management and the personnel management function. Furthermore, doing this makes it possible to integrate communication with employees and external market communication, while increasing the synergy effect between the employees as ambassadors in the local community and the direct market and PR communication. ${ }^{66}$

Longo, Mura and Bonoli concluded and emphasised connection between a number of companies with good social and environmental records. Such records indicate that these activities can result in better performance and can generate more profits and growth. Authors stress that Commission of the European Communities found that social activity can lead to economic rewards and business should attempt to create such a favourable situation. ${ }^{67}$ Finally, CSR to some extent can contribute to sustainability goals on micro and macro level.

Also, as Fraj-Andres, Lopez-Perez, Melero-Polo and Vazquez-Carrasco survey reveals, some managers think that CSR activities allow some type of differentiation and have a greater consideration for competitors and customers,

$\begin{array}{ll}{ }_{62} & \text { Ibidem } \\ 63 & \text { Nagypál, N. C., } 346 . \\ 64 & \text { Ibidem } \\ { }^{65} & \text { Ellerup Nielsen A., Thomsen, C., } 186 . \\ { }_{66} & \text { Ibidem } \\ 67 & \text { Longo, M., Mura, M., Bonoli A., } 41 .\end{array}$


therefore it is essential for companies to be market-oriented since this will allow them to adapt constantly to future changes that may occur in social, economic, technological and legislative aspects. ${ }^{68}$ In the end, as Barthorpe also concludes, businesses need to take CSR more seriously than ever before, not only as a feel-good exercise but to consider CSR as being of strategic and financial importance to every business. ${ }^{69}$

\section{Literature}

- Ayuso, S., Roca, M., Colome, R. (2013): "SMEs as "transmitters" of CSR requirements in the supply chain", Supply Chain Management: An International Journal, 5, 497-508, http://dx.doi.org/10.1108/SCM-04-2012-0152 (19.04.2015)

- Barthorpe, S. (2010): "Implementing corporate social responsibility in the UK construction industry", Property Management, 1,2010(1), 4-17 , http://dx.doi.org/10.1108/02637471011017145 (19.04.2015)

- $\quad$ Ellerup Nielsen, A., Thomsen, C. (2009): "CSR communication in small and medium- sized enterprises: A study of the attitudes and beliefs of middle managers", Corporate Communications: An International Journal, 2, 2009, 176-189, http://dx.doi.org/10.1108/13563280910953852 (16.04.2015)

- Fassin, Y. et al. (2015): "CSR and Related Terms in SME OwnerManagers' Mental Models in Six European Countries: National Context Matters", Journal of Business Ethics, 2, 433-456 http://link.springer. com/article/10.1007\%2Fs10551-014-2098-7 (19.04.2015)

- Fraj-Andres, E., Lopez-Perez, M. E., Melero-Polo, I., VazquezCarrasco, R. (2012): "Company image and corporate social responsibility: reflecting with SMEs' managers", Marketing Intelligence \& Planning, 2, 266-280, http://dx.doi.org/10.1108/02634501211212019 (19.04.2015)

- Franco, M., Santos, M. de F., Ramalho, I., Nunes, C. (2014): “An exploratory study of entrepreneurial marketing in SMEs: The role of the founder-entrepreneur", Journal of Small Business and Enterprise Development, 2014(2), 265-283, from http://dx.doi.org/10.1108/JSBED-10-2012$0112(19.04 .2015)$

- García, M., Castillo Díaz, A., Carrillo Durán, V. (2012): “Online corporate communication: SMEs and differences across sectors", Journal of Organizational Transformation \& Social Change, 3, 2012, 285300, http://www.maneyonline.com/doi/abs/10.1386/jots.9.3.285_1 (19.04.2015)

- Hoivik, H. von W. (2011): "Embedding CSR as a learning and knowledge creating process: the case for SMEs in Norwa", Jour-

68 Fraj-Andres, E., Lopez-Perez, M. E., Melero-Polo, I., Vazquez-Carrasco, R., 277.

69 Barthorpe, S., 7.

Vol. 12, No 3, 2015: 215-230 
nal of Management Development, 10, 1067-1084, http://dx.doi. org/10.1108/02621711111182547 (19.04.2015)

- Longo, M., Mura, M. and Bonoli, A. (2005): "Corporate social responsibility and corporate performance: the case of Italian SMEs", Corporate Governance, 4, 28-42, http://dx.doi.org/10.1108/14720700510616578 (19.04.2015)

- Nagypál, N. C. (2014): "Corporate social responsibility of Hungarian SMEs with good environmental practices", Journal for East European Management Studies, 3,2014, 327-347, http://www.hampp-ejournals. de/hampp-verlag- services/get?file=/frei/JEEMS_3_2014_Nagypal (19.04.2015)

- Pistol, L., Tonis, L. (2014): "Models of marketing simulations for SMES in Romania: Strategic game for marketing mix simulation", Contemporary Readings in Law and Social Justice, 1, 501-509, http://connection. ebscohost.com/c/articles/97217863/models-marketing-simulations http://dx.doi. org/10.1108/13563281211196344-smes-romania-strategic-game- marketing-mix-simulation (19.04.2015)

- Schmeltz, L. (2012): "Consumer-oriented CSR communication: focusing on ability or moralit”,. Corporate Communications: An International Journal, 1, 29-49, http://dx.doi.org/10.1108/13563281211196344 (19.04.2015)

- Sones, M., Grantham, S. (2009): “Communicating CSR via pharmaceutical company web sites: Evaluating message frameworks for external and internal stakeholders", Corporate Communications: An International Journal, 2, 2009, 144-157, http://dx.doi.org/10.1108/13563280910953834 (19.04.2015)

Paper received: May 22 $2^{\text {nd }}, 2015$

Approved for publication: June $13^{\text {th }}, 2015$
Rad primljen: 22. maj 2015. Odobren za štampu: 13. jun 2015. 
Mr Ana Mulović

Sveučilište Sjever, Koprivnica, Hrvatska

Doc. dr Anica Hunjet

Sveučilište Sjever, Koprivnica, Hrvatska

Prof. dr Goran Kozina

Sveučilište Sjever, Koprivnica, Hrvatska

\section{KA EKONOMSKOM NAGRAĐIVANJU: KORPORATIVNA DRUŠTVENA ODGOVONOST U POSLOVNIM KOMUNIKACIJAMA MSP}

\section{S a ž e t a k}

U poslovnom svetu danas, mala i srednja preduzeća (MSP) dobijaju sve značajniju ulogu. Trenutno, smatra se da MSP čine okosnicu ekonomskog rasta u mnogim zemljama, doprinoseći kreiranju novih radnih mesta i snabdevajući dobrima i uslugama velike kompanije. U međunarodnim okvirima, različite studije podvlače značaj MSP za privredni razvoj jedne zemlje i za njenu ekonomsku stabilnost. MSP igraju značajnu ulogu u privredama evropskih zemalja i, za mnoge autore, njihova organizaciona forma je noseći stub poslovne strukture. $\mathrm{Na}$ više načina autori podvlače značaj korporativne društvene odgovornosti kao mantre našeg vremena, koje su okarakterisali kao „vreme saosećajnog kapitalizma“ ili „vek održivosti“. Korporativna društvena odgovornost u poslovnim komunikacijama MSP je značajan element strateškog pristupa komunikacijama, koji počiva na ideji da preduzeća mogu da kreiraju snažan identitet primenjujući sistematsku i proaktivnu praksu komuniciranja unutar svojih organizacija, stvarajući tako put ka „izgradnji i očuvanju dobre reputacije i odnosa sa ključnim stejkholderima“.

Ključne reči: korporativna društvena odgovornost, korporativna društvena odogovornost u poslovnim komunikacijama, mala i srednja preduzeča (MSP) 